\title{
Nano-Scale Spheroids and Fossils from the Ediacaran Doushantuo Formation in China
}

\author{
Tenger Borjigin ${ }^{1}$, Leiming Yin ${ }^{2, *}$, Lizeng Bian ${ }^{3}$, Xunlai Yuan ${ }^{2}$, Chuanming Zhou ${ }^{2}$, Fanwei Meng ${ }^{2}$, \\ Xiaomin $\mathrm{Xie}^{1}$ and Fang Bao ${ }^{1}$
}

\author{
${ }^{1}$ Key Laboratory of Petroleum Accumulation Mechanisms, Wuxi Research Institute of Petroleum Geology, SINOPEC, \\ Wuxi 214151, Jiangsu, China \\ ${ }^{2}$ State Key Laboratory of Palaeobiology and Stratigraphy, Nanjing Institute of Geology and Palaeontology, Chinese \\ Academy of Sciences, Nanjing 210008, Jiangsu, China \\ ${ }^{3}$ School of Earth Sciences and Engineering, Nanjing University, Nanjing 210008, Jiangsu, China
}

\begin{abstract}
Exceptionally preserved nano-scale spheroids derived from microbial processes and nano-scale fossils have been discovered from the black shales of the Jijiawan section of the Ediacaran Doushantuo Formation in the Yangtze Gorge area of Hubei Province, southern China. The numerous soccer ball-like spheroids are pyritized. Their morphology and abundant preservation may suggest that they could possibly be related to larger spheroids, regardless of the tremendous dimensional gap found in the phosphorite and cherts of the Doushantuo Formation, including those recognized as 'embryos'. The colony-like spheroids preserved in situ and obtained by acid maceration are compared with known Neoproterozoic microfossils-Bavlinella faveolata (or Sphaerocongregus variabilis). Additionally, nano-scale fossil bodies, characterized by morphological features comparable to living cyanobacteria, fungi and possible unicellular heterotrophic protists were observed in different minor laminae of the black shale samples. This study aims to reveal the aspects of nano-scale biota preserved in the black shale of the Ediacaran Doushantuo Formation, and highlight the taphonomy of microorganisms during the key transition from the anoxic deeper oceans to the oxygenated oceans of the early Ediacaran interval.
\end{abstract}

Keywords: Nano-scale spheroids and fossils, Ediacaran, Doushantuo Formation.

\section{INTRODUCTION}

Based on geochemical and molecular palaeontological research, the Neoproterozoic Ediacaran period has been considered a key transition point in the geological history of the Earth [1-3]. Ediacaran fossil discoveries, including the first appearance of large and diverse soft-bodied organisms, basal unicellular protists (acanthomorphic acritarchs), animal embryos and various seaweeds, indicate that the members of the Ediacaran biota arose shortly after the last Neoproterozoic glaciation. This evidence suggests that there was a causal link between their evolution and the oxygenation event $[1,2,4]$. Geochemical data indicate that oxygenation of the deep ocean happened in the mid-Ediacaran period [37]. Thus, it seems likely that atmospheric oxygen was a key factor in the development of Ediacaran fauna. However, as yet, no compelling fossil record has been produced as evidence of the biota for the early Ediacaran relatively anoxic, ferruginous ocean.

*Address correspondence to this author at the State Key Laboratory of Palaeobiology and Stratigraphy, Nanjing Institute of Geology and Palaeontology, Chinese Academy of Sciences, Nanjing 210008, Jiangsu, China; Tel: 0086-025-83282240; E-mail: 1myin2012@gmail.com

\section{GEOLOGICAL SETTING}

The 635-551 Ma Ediacaran Doushantuo Formation [8] is sandwiched between the underlying Nantuo tillites and the overlying dolomites of the Dengying Formation in southern China. Since the 1970s, many significant permineralized fossils, including acanthomorphic acritarchs, eukaryotic algae, animal embryos, diapause egg cysts, lichen and possible microscopic animals have been found in the cherts and phosphates of the Doushantuo Formation [9-15].

Here, we report on a new discovery of nano-scale fossils, and nano-scale spheroids derived from microbial processes, preserved within the black shales of the Jijiawan section of the Ediacaran Doushantuo Formation in the Yangtze Gorge area of Hubei Province, South China.

The Jijiawan section is located on the western limb of the Huangling Anticline in the Yangtze Gorges area $\left(30^{\circ} 52^{\prime} 54.4^{\prime \prime} \mathrm{N}, 110^{\circ} 52^{\prime} 38.2^{\prime \prime} \mathrm{E}\right)$ (Fig. 1). According to geochemical data acquired for the Jijiawan and other sections in the Yangtze Gorge area [6, 16, 17], the black shale bed contains abundant organic matter $[\omega(\mathrm{Corg}) \%=$ 3.98 ] and is characterized as a horizon that contains a notable negative peak value of carbonate $\left(\delta^{13} \mathrm{Ccarb}\right)$ (Fig. 1). The shale samples are positioned just beneath beds containing abundant and diverse acanthomorphic acritarchs, red algae 

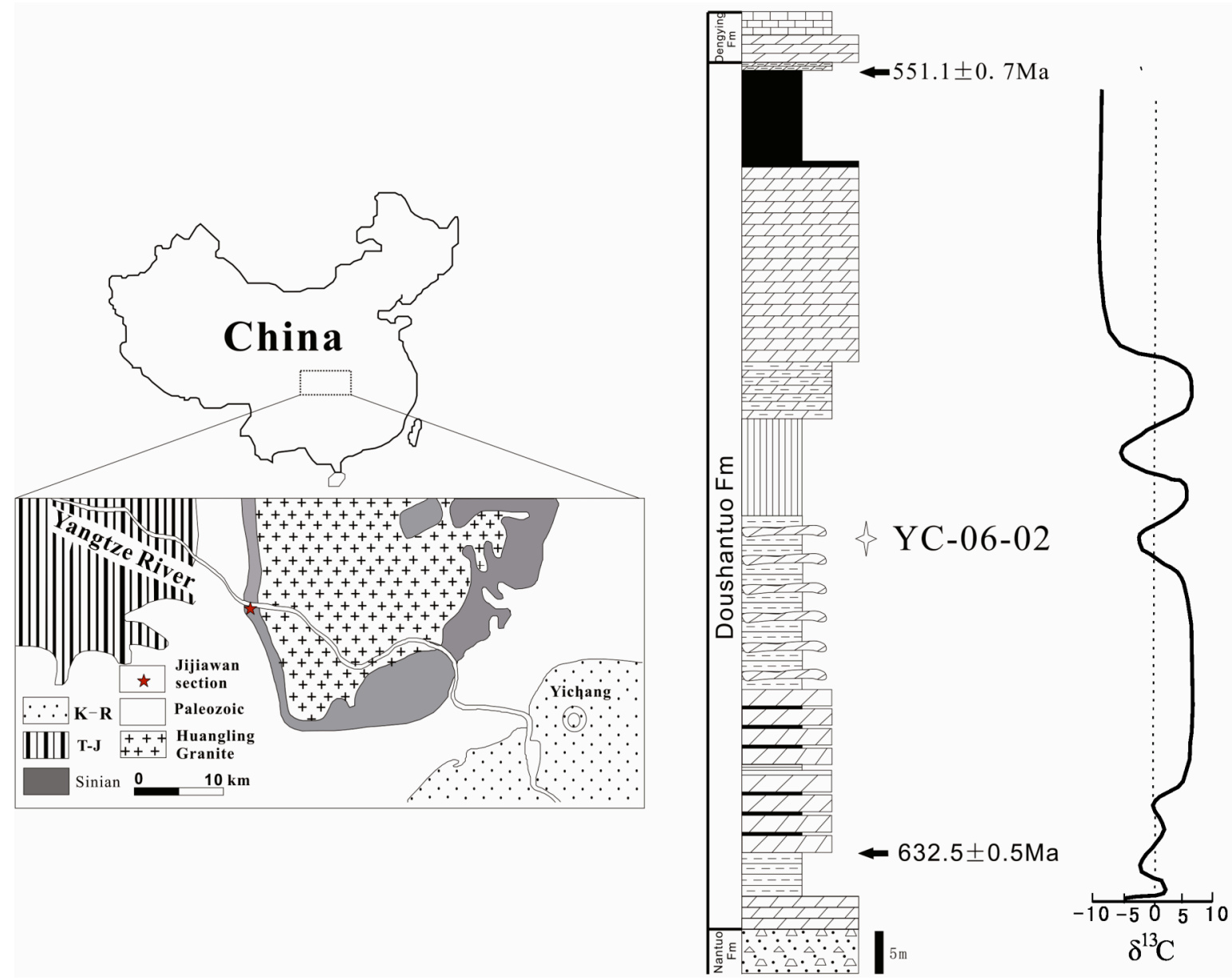

Fig. (1). Sketch map showing localities of both the Ediacaran Doushantuo Formation of the Jijiawan section in the Yangtze Gorge area, western Hubei, China, and the sampling location (No. YC-06-02). A generalized $\delta^{13} \mathrm{C}$ stratigraphic column of the Doushatuo Formation by Zhu et al. (2013) indicates that the sampled bed occurs in a negative part of the $\delta^{13} \mathrm{C}$ curve.

and micrometazoans found from other sections of the Doushantuo Formation $[6,18,19]$. The black shale bed has a likely age of about $600 \mathrm{Ma}$, based on a $632.50 \pm 0.48 \mathrm{Ma}$ U$\mathrm{Pb}$ zircon dating for the ash bed lying $9.5 \mathrm{~m}$ above the base of the Doushantuo Formation, a $550.55 \pm 0.55 \mathrm{Ma} \mathrm{U}-\mathrm{Pb}$ zircon dating for the ash bed in the uppermost Doushantuo Formation in the studied section [8], and adopting the reference of a $614.0 \pm 7.6 \mathrm{Ma}$ zircon SHRIMP $\mathrm{U}-\mathrm{Pb}$ age for the mid-Doushantuo Formation in the Zhangcunping section of the Yangtze Gorge area [20].

\section{METHODS}

The black shale samples studied here were collected from a horizon $70 \mathrm{~m}$ above the base of the Doushantuo Formation in the Jijiawan section.

Nano-scale spheroids and fossils were preserved in situ and examined using SEM (performed on a LEO 1530, JSM 6300 at the Nanjing Institute of Geology and Palaeontology and Wuxi Research Institute of Petroleum Geology) on fresh samples of the black shale that were either left uncoated or coated with gold (gilded). They occur in different minor laminae, which are characterized either by abundant pyrite or the presence of distinct gypsum minerals. The uncoated and gilded specimens were used to determine elemental composition using a computerized energy-dispersive X-ray micro-analyser system (EDX). In addition, some specimens preserved in situ were analysed by Raman spectroscopy (performed on a Renishaw in via at the Wuxi Research Institute of Petroleum Geology) to provide information on their material components and molecular structure. The measurements were performed on polished rock specimens to determine Raman spectra for both nano-scale spheroids and adjoining pyrite framboids.

To further characterize the observed spheroidal structures and nanofossils under SEM, rock samples were macerated with diluted hydrochloric and hydrofluoric acids to obtain organic residues. Some uncoated specimens, which were selected from organic residues, were analyzed for their elemental composition using EDX.

\section{RESULTS}

In the study, nano-scale spheroids obtained by acid maceration from the sampled black shale of the Doushantuo Formation and observed under SEM could be represented by individual and colony-like forms. Individual forms include soccer ball-like spheroids characterized by polygonal cracks, and simple spheroids showing sub-spherical to spherical aspects that normally display wall-like vesicles and hollow interiors. These are all preserved in situ with an amorphous aggregation or scattered distribution (Fig. 2A). 


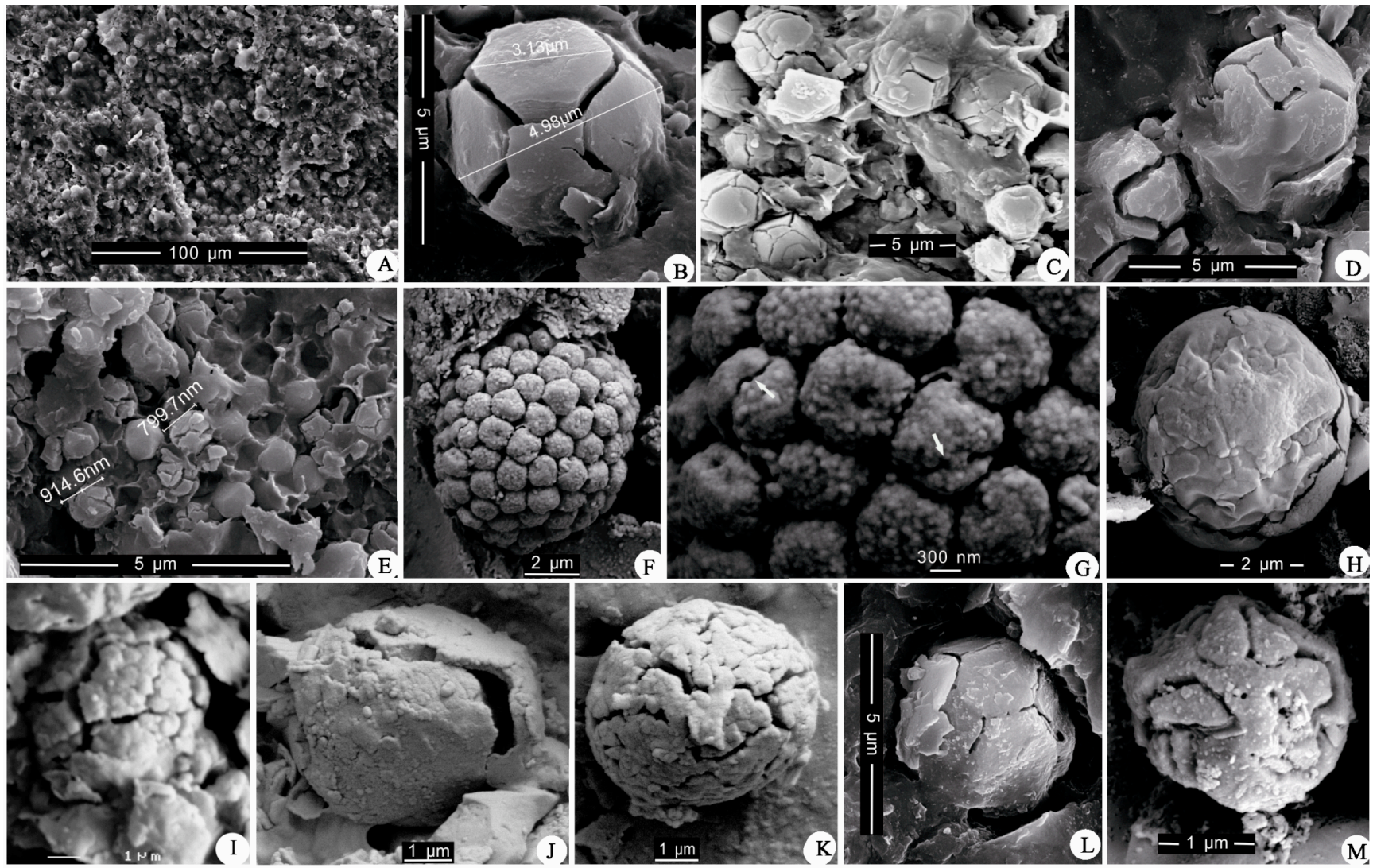

Fig. (2). Nano-scale spheroids found in the black shales of the Ediacaran Doushantuo Formation in the Jijiawan section, Hubei, China.

A-E, I, L, M Soccer ball-like spheroids with probable hollow interior and polygonal cracks, preserved in situ (except specimen M, which was obtained by acid maceration); specimen I displays tuberculiform ornamentation on its surface. F, G colony-like spheroids, which were obtained from organic residues of acid maceration and are compared with known fossils - Bavlinella faveolata. G is a magnification of part of $\mathbf{F}$ to show ductile walls (arrow) and possible fine ornamentation on the surface. $\mathbf{H}, \mathbf{J}, \mathbf{K}$ single spheroids with hollow cavities, $\mathbf{H}$ was obtained from organic residues of acid maceration, $\mathbf{J}$ and $\mathbf{K}$ are preserved in situ.

The soccer ball-like spheroids are embedded in the membraniform clay minerals of the host rock and preserved in situ together with a few pyrite framboids. Most spheroids were nearly the same size (4-5 $\mu \mathrm{m}$ in diameter, $\mathrm{n}=250)$, but some were smaller $(3 \mu \mathrm{m}, \mathrm{n}=60)$ and the smallest diameter was $<1 \mu \mathrm{m}(\mathrm{n}=25)$. Single spheroid specimens commonly had about eight scalene pentagon-hexagon (Fig. 2B-E, L) or irregular polygonal partitions (Fig. 2M) cleaved by grooves. A few specimens display tuberculiform ornamentation on their surfaces (Fig. 2I). Even though all of the spheroids contain distinctively high amounts of carbon and organic matter (based on EDX spectra (Fig. 4, Table 1) and Raman spectra (Fig. 5), they showed pyritization to different degrees, or sometimes merely ferrugination and sulfuration. Their Fe/S ratios varied from 3:1 to nearly 45:1 (see Table 1C), while containing both iron and sulfur.

A few solitary and slightly larger spheroidal specimens (Fig. 2K, J), preserved together with the soccer ball-like spheroids in the same minor laminae or laminae-bearing gypsum minerals, displayed similar pyritization and sulfuration. A few specimens (Fig. 2H) showed weak sulfuration or other mineralization containing calcium or silicon in their EDX spectra.

Another notable colony-like form has been obtained from organic residues of acid maceration and observed under
SEM. These specimens (Fig. 2F; Fig. 4E) resemble pyrite framboids in their rough morphology, but they display celllike units rather than pyrite crystals or pyrite spheres, because of their plastic 'cell walls' and empty interiors (Fig. 2F, G). The EDX spectra of these specimens shows that the element contents are different, which indicates that they have weak ferrugination or sulfuration and no remarkable mineralization, only containing carbon, oxygen and other minerals (Fig. 4I). Moreover, the fact that such specimens (Fig. 2F) were obtained by acid maceration, might be implied by the nature of their acid resistant organic walls.

In addition, some nano-scale morphological bodies have been discovered under SEM in minor lamina containing gypsum minerals within the black shale sample. Based on their physical features, jar-like and oblate morphological forms can be recognized. The jar-like specimens (Fig. 3D, E, F), 4-7 $\mu \mathrm{m}$ in length and 3-5 $\mu \mathrm{m}$ wide $(\mathrm{n}=12)$, display a horn-like circular loop at one end of the ellipsoidal body, exhibiting lengthways ridged thickenings (or 'ornamentation'). We assume that they are hollow, because some observed specimens were compressed (Fig. 3E). They normally appear individually, with only occasional connections between one another. Their EDX spectra show either weak ferrugination containing a small amount of sulfur or show only the curved peak of carbon. 

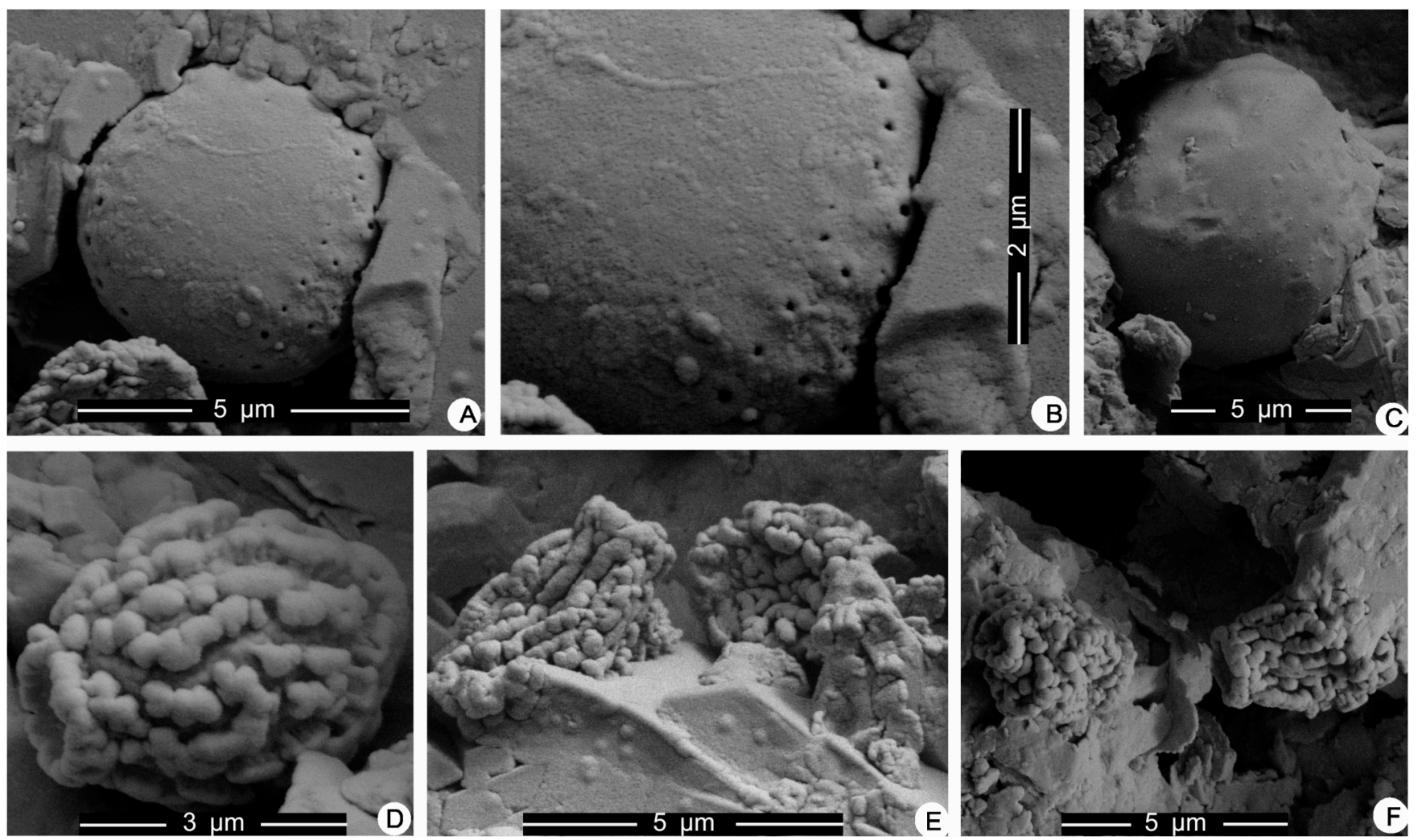

Fig. (3). Nano-scale fossils found in the black shales of the Ediacaran Doushantuo Formation in the Jijiawan section, Hubei, China.

A, B nano-scale oblate body with minute holes around its margin, $\mathbf{B}$ is a magnification of part of $\mathbf{A}$ to show detail of minute holes. $\mathbf{C}$ nanoscale oblate body with no obvious ornamentation. D, E, F jar-like bodies ornamented with ridge-like protuberances.

Table 1. Results from the energy-dispersive X-ray micro-analyzer system (EDX) for the Doushantuo nano-scale spheroids and fossils.

\begin{tabular}{|c|c|c|c|c|c|c|c|c|}
\hline \multirow[t]{2}{*}{ Element } & \multicolumn{2}{|c|}{$\begin{array}{c}\text { (A) } \\
\text { Eight Specimens }\end{array}$} & \multicolumn{2}{|c|}{$\begin{array}{c}\text { (B) } \\
\text { Six Specimens }\end{array}$} & \multicolumn{2}{|c|}{$\begin{array}{c}\text { (C) } \\
\text { Twenty-Five Specimens }\end{array}$} & \multicolumn{2}{|c|}{$\begin{array}{c}\text { (D) } \\
\text { Two Specimens }\end{array}$} \\
\hline & $w t \%$ & at $\%$ & $w t \%$ & at $\%$ & $w t \%$ & at $\%$ & wt $\%$ & at $\%$ \\
\hline $\mathrm{C}$ & $2.71-39.95$ & $5.07-52.92$ & $1.43-39.75$ & $18.27-55.82$ & $3.90-20.01$ & $7.85-27.15$ & $33.22-100$ & $54.95-100$ \\
\hline $\mathrm{O}$ & $19.15-51.49$ & $29.35-68.13$ & $0.35-67.25$ & $3.39-64.50$ & $40.83-47.94$ & $52.20-62.68$ & 23.66 & 29.39 \\
\hline $\mathrm{Mg}$ & $2.32-8.97$ & $2.00-3.38$ & $1.03-8.97$ & $0.65-6.23$ & $1.70-9.88$ & $1.64-7.46$ & & \\
\hline $\mathrm{Ca}$ & $9.07-10.26$ & $0.83-4.89$ & $0.68-9.07$ & $1.23-3.81$ & $0.45-2.81$ & $0.22-1.70$ & 5.74 & 2.85 \\
\hline $\mathrm{Fe}$ & $22.96-40.77$ & $8.70-17.57$ & & & $10.79-51.75$ & $3.55-24.46$ & 38.73 & 13.78 \\
\hline S & $14.54-22.89$ & $10.92-16.05$ & & & $0.37-7.34$ & $0.21-15.75$ & & \\
\hline $\mathrm{Si}$ & $4.73-18.67$ & $4.06-11.21$ & 19.39 & 1.40 & $3.67-11.68$ & $2.90-7.63$ & -1.36 & -0.96 \\
\hline $\mathrm{Al}$ & $0.74-4.38$ & $0.66-2.74$ & & & $0.58-1.31$ & $0.51-2.08$ & & \\
\hline
\end{tabular}

(A) Spheroids with pyritic molds and pyrite framboids (no coating). (B) Isolated and colony-like spheroids with no obvious ornamentation (four specimens had no coating and two had gold coating). (C) Soccer ball-like spheroids (no coating). (D) Jar-like bodies (gold coating). 

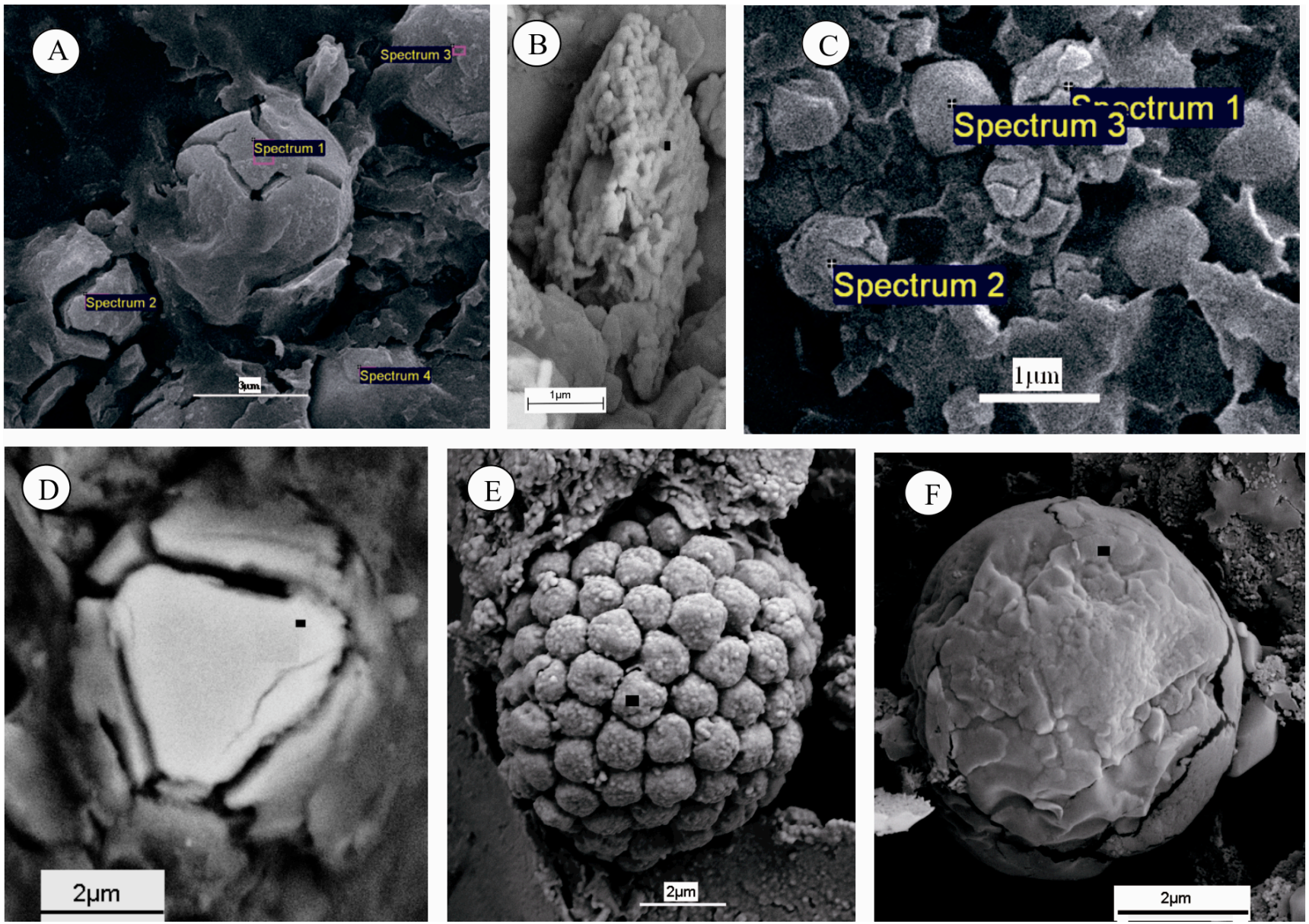

Fig. (4). Locations (marked with 'spectrum' or small black diagram) of EDX measurements for nano-scale spheroids and fossils from the Ediacaran Doushantuo Formation in the Jijiawan section, Hubei, China.

A, C, D Soccer ball-like spheroids. B Jar-like body. E Colony-like spheroid, obtained from organic residues of acid maceration. F Isolated spheroid, obtained from organic residues of acid maceration.

The oblate body, ringed with tens of minute holes, was about $5 \mu \mathrm{m}$ in size and was embedded in gypsum crystals and clay minerals (Fig. 3A, C). Under high-powered SEM, the minute holes display different dimensions (Fig. 3B) distributed at distances of $300-500 \mathrm{~nm}$. Some of the slightly larger holes had rising circular aperture edges. Only one such specimen is confirmed; other similar specimens are questionable because they do not show the minute holes (Fig. 3C).

\section{DISCUSSION}

Based on studies of lithology, biostratigraphy and geochemistry, the Ediacaran Doushantuo succession in the Yangtze Gorges area is inferred to be deposited on a rimmed carbonate shelf with a shelf-margin barrier separating the shelf lagoon from the open ocean [21]. The Doushantuo Formation was deposited at greater depths in the intra-shelf basin during the same geological period [18]. The studied samples were collected from interbedded organic-rich black shale of bedded dolostone from the lower part of the Jijiawan section, where there is an obvious, but small, negative peak in $\delta^{13} \mathrm{C}$. Compared with adjacent sections, such as the Miaohe and Jiulongwan sections in the Yangtze Gorge area, the depositional environment of the sample should lie near the transition from anoxic/euxinic deeper water to oxygenated shallower water $[21,22]$. The presence of variable minor laminae containing either pyrite or gypsum might correspond to fluctuations in the environment of deposition during the geological time interval. This supports the interpretation of a stratified redox model for the Ediacaran Ocean where it is observed in the Nanhua Basin $[22,23]$. The fact that the minor laminae containing abundant nano-scale pyritized spheroids and framboidal pyrite changed immediately $(<0.5 \mathrm{~mm}$ thick $)$ in the above minor laminae, with gypsum, preserving nano-scale unicellular fossils, indicates that the depositional environment likely was euxinic near the water-sediment interface. This interpretation is supported by both the known fossil record of the Ediacaran Lantian Formation in Anhui, China [24], and the study of framboidal pyrite in modern sediments [25]. The studied nano-scale spheroids and fossils were preserved in black shale formed in redox conditions.

Nano-scale spheroids of the Doushantuo Formation, especially those presenting as soccer ball-like spheroids, are distinguished from normal pyrite crystals, pyrite spheres similar to those reported from Devonian black shales in North America [26] or euhedral crystals in external morphology [27]. They only occur in minor laminae with pyrite framboids or pyrite crystals and indicate a transition from sulfuration, ferrugination to pyritization, based on the 

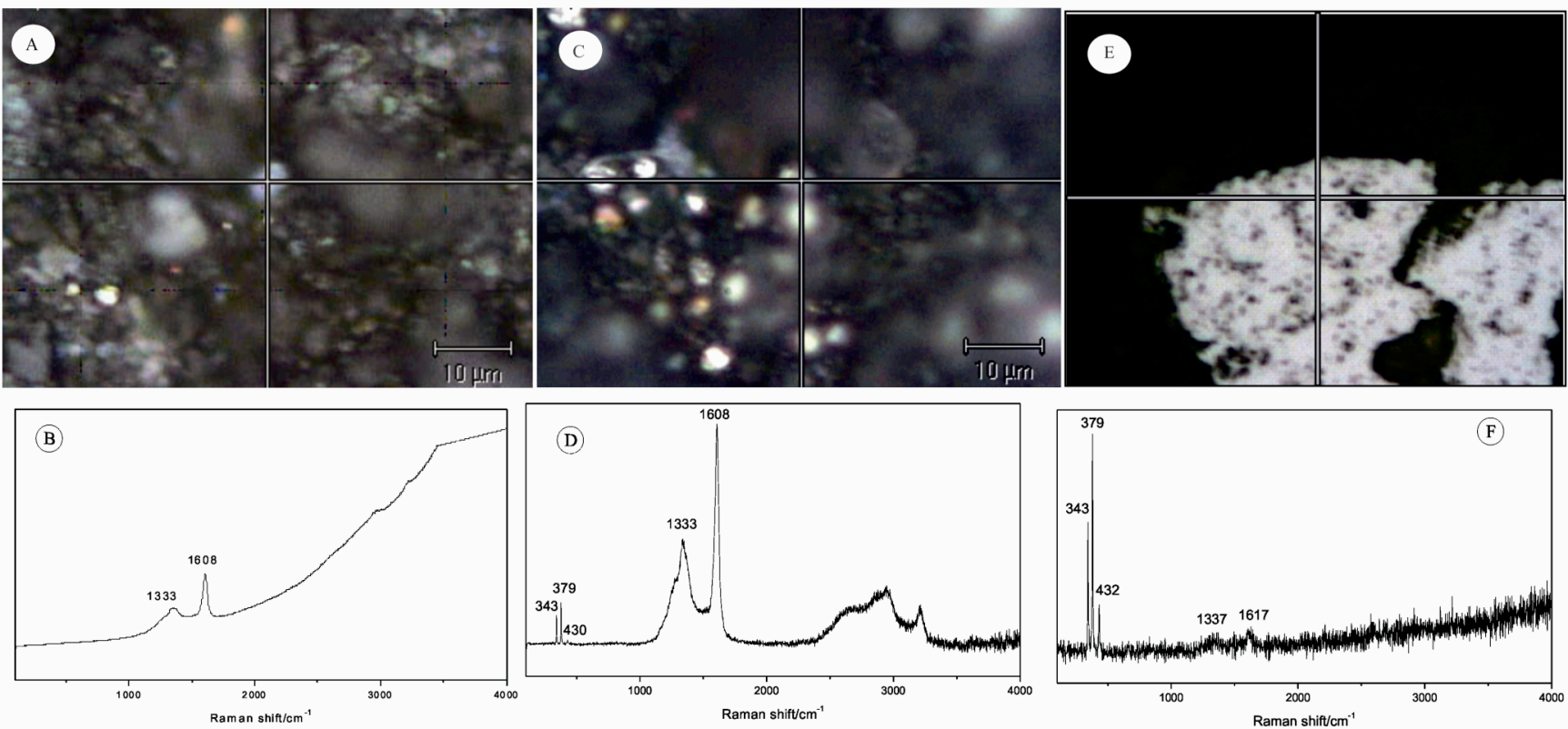

Fig. (5). Raman microspectroscopy. The point of crosswire in photos $\mathbf{A}, \mathbf{C}$, and $\mathbf{E}$ indicates the location of Raman detection.

A, B Isolated spheroidal specimen with Raman spectrum showing the 1333 and $1608 \mathrm{~cm}^{-1}$ bands of carbonaceous (organic) matter. C, D Soccer ball-like spheroid specimen with Raman spectrum showing the 343,379 and $432 \mathrm{~cm}^{-1}$ bands of pyrite and 1333 and $1608 \mathrm{~cm}^{-1}$ bands, and three wider and gentle curve peaks between the 2500 and $3250 \mathrm{~cm}^{-1}$ bands of carbonaceous (organic) matter. E, F Pyrite framboids with Raman spectrum showing distinct 343,379 and $432 \mathrm{~cm}^{-1}$ bands and very weak curve peaks at the 1337 and $1617 \mathrm{~cm}^{-1}$ bands of carbonaceous material (graphite).

analysis of EDX spectra (Table 1). Such specimens might represent microbiotic remains that were altered mainly by pyritization. This interpretation can be supported by Raman spectra analysis (Fig. 5C). Although the measured soccer ball-like spheroid shows characteristic Raman spectra curves of pyrite $\left(\mathrm{FeS}_{2}\right)$ at the 343,379 and $432 \mathrm{~cm}^{-1}$ bands, it displays remarkable Raman point spectra at the 1333 and $1608 \mathrm{~cm}^{-1}$ bands and three wider and gently curved peaks between 2500 and $3250 \mathrm{~cm}^{-1}$ bands (Fig. 5C, D), which are recognized as having characteristic Raman spectral peaks for carbonaceous (organic) matter [28]. The other isolated spheroid specimen (Fig. 5A) only produced 1333 and 1608 $\mathrm{cm}^{-1}$ bands for carbonaceous (organic) matter (Fig. 5B). In contrast with typical Raman spectra of pyrite framboids or crystals (Fig. 5E, F) preserved in the same minor laminae within a rock sample, spheroids with polygonal cracks are more strongly recognized to have originally been microorganisms, rather than abiotic structures.

In morphological style, regardless of the tremendous dimensional gap, the 'soccer' globules (Fig. 2B, C, D, L, M) are quite similar to some Doushantuo phosphatic mophological forms - particularly Parapandorina, Spiralicellula and Caveasphaera - which have been recognized as animal cleavage embryos [11, 29]. However, present nano-scale specimens do not show distinct 'vesicle walls' and represent a fixed form as a series of cracks. The differences might be the result of varied fossil preservation. So far, well-preserved animal embryo fossils of the Ediacaran Doushantuo Formation are preserved in either phosphatization or silicification in a few later strata. In modern marine embryos, oxygen and nutrition in aquatic environments are important limiting factors to influence development of embryos $[30,31]$. Though the studied nanoscale spheroid specimens are so tiny size for imagining as embryos, the anoxic/euxinic deeper water could be restricted their development. However, the studied nano-scale spheroid specimens were deformed by pyritization during burial preservation. Additionally, the tiny size makes the evaluation of their interior structures very difficult for detailed study on a subcellular level.

In modern microorganisms, a giant sulfur bacterium Thiomargarita - discovered in Namibian Shelf sediments shows similar globules during cell reductive division [32, 33]. However, there are distinct differences between them. The present globules are much smaller than the giant Thiomargarita and no series of reductive cell division like those of Thiomargirita appears in the present spheroids. Furthermore, precipitation of phosphorous minerals, which is normally mediated by Thiomargarita [32], has not been found in associating spheroids and even in the studied black shale sample.

In external morphology, the 'soccer' globules look like the spore of living Licea eremophila [34] of the myxomycetes. However, the latter displays raised bands on the surface rather than cracks, and moreover, no sporocarplike remains have been found from the studied rock samples.

Although the cause of polygonal cracks in the spheroid specimens remains uncertain, their morphology and ready preservation may suggest that nano-scale spheroids preserved in black shale could relate to larger spheroids found in the upper part of the Doushantuo Formation, including those recognized as 'embryos'.

Specimens characterized by isolated spheroids (Fig. $\mathbf{2 H}$, J, K) can be compared with some known coccoid microfossils reported from Proterozoic cherts and black shales in China and elsewhere in the world. For example, 
one form-Nanococcus vulgaris - described by Oehler [35] from the Y.C. Pyritic Shale Member of the Barney Creek Formation, McArthur Group, Australia, is similar to studied isolated spheroids in that they may be characterized by small (normally $<10 \mu \mathrm{m}$ ) isolated spheroids and their loose distribution. Nanococcus vulgaris has been compared with planktonic members of the modern chroococcacean genus Aphanocapsa Nageli [35], but studied isolated spheroids seem to lack an amorphous organic matrix as colony preservation of Aphanocapsa .

The specimens of colony-like spheroids (Fig. 2F) appear to be distinguished from abiotic pyrite framboids [24, 36, 37] and possible greigite framboids [26] by the fact that they display cell-like units, exhibiting relatively larger sizes and plastic characters similar to organic matter deformed or ruptured by compression (Fig. 2F, G). Previously, distinguishing biotic from abiotic processes in the formation of pyrite framboids has not been well understood. The identification of the potential signatures of such activities requires improved understanding of pyrite chemical- and bio-oxidation mechanisms [38]. Among studied specimens, rare ferrum or sulfur and high carbon elements were detected with EDX for some specimens. However, a few specimens obtained by acid maceration (Fig. 2F) only show elemental carbon and oxygen in their EDX spectra. Therefore, such colony-like spheroids may originally have been endosporous microorganisms that were widely distributed in deeper weakly reducing and oxidic conditions, such that they ended up in different taphonomic circumstances.

Similar morphological microfossils, such as Bavlinella faveolata or Sphaerocongregus variabilis, which was interpreted as resembling endosporagia of cynobacteria [39], often occur within extraordinarily low-diversity acritarch assemblages obtained from late Neoproterozoic sediments from ecologically stressed palaeoenvironment [39-42]. The studied specimens are consistent with Bavlinella faveolata with regard to morphological features. As Knoll and Blick (1981) [41] concluded, Bavlinella faveolata represents biological organization different from pyrite framboids on the basis of their organic composition and discrete time range.

The nano-scale jar-like bodies ornamented with ridgelike protuberances (Fig. 3D, E, F) seem to have been discovered first in the Ediacaran Doushantuo Formation of South China.

Previously, vase-shaped forms of microfossils had been discovered in Neoproterozoic sediments in China and elsewhere in the world. Those fossils are characterized by vase- or tear-like shaped tests, consisting of a rounded pole gradually tapering toward a "neck" that ends in a single aperture; their systematic affinity has been suggested to be similar to that of testate amoebae [43]. Present jar-like bodies, although also displaying a similar jar- or 'vase'shape, differ from vase-shaped microfossils in having a horn-like annulation at one pole and ridge-like protuberances on their surface. Thus, the jar-like bodies, at present, cannot be referred to simply as vase-shaped microfossils with an affinity to amoebae. Additionally, based on hollow cavities found in the jar-like bodies, the morphology of the bodies is similar to fungal spores [44].
In the minor gypsum mineral-bearing laminae, the occurrence of specimens containing an oblate body with two or three rows of numerous minute holes or with no obvious ornamentation (Fig. 3A , C) could imply that the alteration of nano-scale fossil association was accompanied by changes in depositional and taphonomic circumstances from deeper reducing conditions to shallower evaporative conditions. So far, only one specimen bears numerous minute holes. These holes are presumed to have been preserved as primitive structures, because they are unlikely to have formed by secondary diagenetic or taphonomic distortion and such structures could not be the result of mineral dissolution, since the studied specimen is preserved in situ in black shale rather than extracted by acid maceration. Based on their rather simple smooth oblate-spheroid morphology, the specimens are comparable to unicellular algae. However, the observed morphological character with numerous minute holes along its margin is not known in either fossil records or living forms of unicellular algae. Therefore, the presence of the minute holes could be traces of a biological function such as breathing holes or some receptacle for moving structures like cilia. The former case may be a more reasonable interpretation because in that case it could remain as a unicellular heterotrophic protist. However, the hypothesis requires confirmation using similar specimens and supplemental evidence.

Although the above comparisons and discussion of the nanoscale fossils or spheroids are based mainly on morphology and the analysis of limited elemental compositions and organic material, they may enhance our views on the diversity of life and the mechanisms of its preservation at the time of the early Ediacaran anoxic, ferruginous ocean.

\section{CONCLUSIONS}

Morphological features similar to those of modern cyanobacteria characterize the preservation of nano-scale fossils [45]. Possible fungal spore and unicellular heterotrophic protists may imply that a diverse nano-scale biota, including prokaryotes and heterotrophic eukaryotes, existed in the early Ediacaran anoxic deeper ocean. Although most of the nano-scale spheroids and fossils obtained from the black shale of the lower part of the Doushantuo Formation were strongly carbonized and mineralized, these findings further reveal aspects of life during this key period of transition from anoxic deeper oceans to oxygenated oceans.

Consequently, the investigation of the biological link that may have existed between such nano-scale microbes and much larger microfossils, particularly acanthmorphic acritarchs, animal embryos and other possible animal remains, during the earlier Ediacaran period is significant. Mineralogically, the studied black shales contain abundant pyrite and gypsum, which alternate within thin laminae. This may signify that redox conditions were fluctuating and a semi-enclosed marine lagoonal palaeoenvironment could have been suitable for the sedimentation and diagenesis of the studied Doushantuo black shales. The fact that many specimens of colony-like spheroids are comparable in their nano-scale biotic associations to Bavlinella faveolata and other cyanobacteria may suggest that an extraordinarily 
stressed environment existed during this key geological interval.

\section{CONFLICT OF INTEREST}

The authors confirm that this article content has no conflicts of interest.

\section{ACKNOWLEDGEMENTS}

We are grateful to Andrew H. Knoll for discussions and significant suggestions during preparation of the manuscript and to two anonymous reviewers for helpful comments. Guoliang Tao and Qigui Jiang are thanked for fieldwork assistance; Fengbao Huang is thanked for palynological maceration. The assistance of Yonxiang Mao, Chunzhao Wang and Zhang Qingzhen with the SEM work is appreciated. The work was supported by the National Natural Science Foundation of China (40839910, 41130209) and State Key Laboratory of Palaeobiology and Stratigraphy (Nanjing Institute of Geology and Palaeontology, CAS (No. Y326150507).

\section{REFERENCES}

[1] Knoll AH. The early evolution of eukaryotes: a geological perspective. Science 1992; 256: 622-7.

[2] Knoll AH, Walter MR, Narbonne GM, Christie-Blick N. The Ediacaran Period: a new addition to the geologic time scale. Lethaia 2006; 39: 13-30.

[3] Shen Y, Zhang N, Hoffman TG, Paul F. On the coevolution of Ediacaran oceans and animals. Proc Natt Acad Sci USA 2008; 105(21): 7376-81.

[4] Canfield DE, Poulton SW, Narbonne GM. Late-Neoproterozoic deep-ocean oxygenation and the rise of animal life. Science 2007; 315: $92-4$.

[5] Canfield DE, Poulton SW, Knoll AH, et al. Ferruginous conditions dominated later neoproterozoic deep-water chemistry. Science 2008; 321: 949-52.

[6] McdFaden KA, Huang J, Chu XL, et al. Pulsed oxidation and biological evolution in the Ediacaran Doushantuo Formation. Proc Natt Acad Sci USA 2008; 105(9): 3197-202.

[7] Johnston DT, Poulton SW, Goldberg T, et al. Late Ediacaran redox stability and metazoan evolution. EPSL 2012; 335-336: 25-35.

[8] Condon D, Zhu MY, Bowring S, Wang W, Yang AH, Jin YG. U$\mathrm{Pb}$ ages from the Neoproterozoic Doushantuo Formation, China. Science 2005; 308: 95-8.

[9] Zhang Y, Yin LM, Xiao SH, Knoll AH. Permineralized fossils from the terminal Proterozoic Doushantuo Formation, South China. Paleontol Soc Mem 1998; 50: 1-52.

[10] Yuan XL. Hofmann HJ. New microfossils from the Neoproterozoic (Sinian) Doushantuo Formation, Weng'an, Guizhou Province, southwestern China. Alcheringa 1998; 22: 189-222.

[11] Xiao SH, Zhang Y, Knoll AH. Three-dimensional preservation of algae and animal embryos in a Neoproterozoic phosphorite. Nature 1998; 391: 553-8

[12] Chen JY, Oliver P, Li C-W, et al. Precambrian animal diversity: putative phostphatized embryos from the Doushantuo Formation of China. Proc Natl Acad Sci USA 2000; 97(9): 445762.

[13] Yuan XL, Xiao SH, Taylor TN. Lichen-like symbiosis 600 million years ago. Science 2005; 308: 1017-20.

[14] Yin LM, Zhu MY, Knoll AH, Zhang JM, Hu J. Doushantuo embryos preserved inside diapause egg cysts. Nature 2007; 446: 661-3.

[15] Yin LM, Wang D, Yuan XL, Zhou CM. Diverse small spinose acritarchs from the Ediacaran Doushantuo Formation, South China. Palaeoworld 2011; 20: 279-89.

[16] McFadden A, Xiao SH, Zhou CM, Kowalewski M. Quantitative evaluation of the biostratigraphic distribution of acanthomorphic acritarchs in the Ediacaran Doushantuo Formation in the Yangtze Gorges area, South China. Precambrian Res 2009; 173: 170-90.

[17] Zhou CM, Xiao SH. Ediacaran $\delta^{13} \mathrm{C}$ chemostratigraphy of South China. Chem Geol 2007; 237: 89-108.

[18] Zhu MY, Lu M, Zhang JM, et al. Carbon isotope chemostratigraphy and sedimentary facies evolution of the Ediacaran Doushantuo Formation in western Hubei, South China. Precambrian Res 2013; 225: 7-28.

[19] McFadden A, Xiao SH, Zhou CM, Kowalewski M. Quantitative evaluation of the biostratigraphic distribution of acanthomorphic acritarchs in the Ediacaran Doushantuo Formation in the Yangtze Gorges area, South China. Precambrian Res 2009; 173: 170-90.

[20] ]Liu PJ, Yin CY, Gao LZ, Tang F, Chen SM. New material of microfossils from the ediacaran doushantuo formation in the zhangcunping area, yichang, hubei province and its zircon SHRIMP U-Pb age. Chin Sci Bull 2009; 54(6): 1058-64.

[21] ]Jiang G, Shi X, Zhang S, Wang Y, Xiao S. Stratigraphy and paleogeography of the Ediacaran Doushantuo Formation (ca. 635$551 \mathrm{Ma}$ ) in South China. Gondwana Res 2011; 19: 831-49.

[22] Li C, Love GD, Lyons TW, Fike DA, Sessions AL, Chu XL. A stratified redox model for the Ediacaran Ocean. Science 2010; 328: 80-3

[23] Xiao XH, McFadden KA, Peek S, et al. Integrated chemostratigraphy of the Doushantuo Formation at the northern Xiaofenghe section (Yangtze Gorges, South China) and its implication for Ediacaran stratigraphic correlation and ocean redox models. Precambrian Res 2012; 192-195: 125-41.

[24] Yuan XL, Xiao SH, Li J, Yin LM, Cao RJ. Pyritized chuarids with excystment structures from the late Neoproterozoic Lantian formation in Anhui, South China. Precambrian Res 2001; 107: 253 63

[25] Wilkin T, Barnes HL, Brantley SL. The size distribution of framboidal pyrite in modern sediments: an indicator of redox conditions. Geochim Cosmochim Acta 1996; 60: 3897-912.

[26] Achieber J, Baird G. On the origin and significance of pyrite spheres in Devonian black shales of North America. J Sediment Res 2001; 71(1): 155-66.

[27] Bailey JV, Raub TD, Meckler AN, Harrison BK, Raub TMD, Green AM, Orphan VJ. Pseudofossils in relict methane seep carbonates resemble endemic microbial consortia. Palaeogeography, Palaeoclimatology, Palaeoecology 2012; 285: $131-42$

[28] Schopf JW, Kudryavtsev AB. Three-dimensional Raman imagery of Precambrian microscopic organisms. Geobiology 2005; 3: 1-12.

[29] Xiao SH, Knoll AH. Phosphatized animal embryos from the Neoproterozoic Doushantuo Formation at Weng'an, Guizhou, South China. J Paleontol 2000; 74: 767-88.

[30] Hoegh-Guldberg O, Manahan DT. Coulometric measurement of oxygen consumption during development of marine invertebrate embryos and larvae. J Exp Biol 1995; 198: 19-30.

[31] Brante A, Fernández M, Viard F. Limiting factors to encapsulation: the combined effects of dissolved protein and oxygen availability on embryonic growth and survival of species with contrasting feeding strategies. J Exp Biol 2009; 212: 2287-95.

[32] Schulz HN, Schulz HD. Large sulfur bacteria and the formation of phosphorite. Science 2005; 307: 416-8.

[33] Bailey JV, Joye SB, Kalanetra KM, Flood BE, Corsetti FA. Evidence of giant sulfur bacteria in neoproterozoic phosphorites. Nature 2007; 445: 198-201.

[34] Wrigley de Basanta D, Lado C, Estrada-Torres A. Licea eremophila, a new myxomycete from arid areas of South America. Mycologia 2010; 102: 1185-92.

[35] Oehler DZ. Microbiota of the middle Protreozoic Balbirini Dolomite (McArthur Group) of Australia. Alcheringa 1978; 2: 269 309.

[36] Butler I, Rickard D, Grimes S. Framboidal Pyrite: self organisation in the Fe-S system. J Conf Abstr 2000; 5(2): 276 (Cambridge Publications).

[37] Ohfuji H, Rickard DD. Experimental syntheses of framboids - a review. Earth-Sci Rev 2005; 71: 147-70.

[38] Cavalazii B, Barbieri R, Cady SL, et al. Iron-framboids in the hydrocarbon-related Middle Devonian Hollard Mound of the AntiAtlas mountain range in Morocco: evidences of potential microbial biosignatures. Sediment Geol 2012; 263-264: 83-93

[39] Moorman M. Microbiota of the late proterozoic Hector formation, southwestern Alberta, Canada. J Paleontol 1974; 48: 524-39. 
[40] Vidal G. Late Precambrian microfossils from the Visingsö Beds in Southern Sweden. Fossils Strata 1976; No.9: pp. 1-57.

[41] Knoll AH, Blick N, Awramik SM. Stratigraphic and ecologic implications of late Precambrian microfossils from Utah. Am J Sci 1981; 281: 247-63.

[42] Yin LM. Microibota from Middle and Late Proterozoic iron and maganese ore deposits in China. Sediment 1990; 11: 109-18.

[43] Susannah M, Porter SM, Knoll AH. Testate amoebae in the Neoproterozoic Era: evidence from vase-shaped microfossils in the Chuar Group, Grand Canyon. Paleobiology 2000; 26(3): 360-85.
[44] Graham A. The role of myxomyceta spores in polynology(with a brief note on the morphology of certain algal zygospores). Rev Palaeobotan Palynol 1971; 11: 89-99.

[45] Stanevich AM. Relics of marine bacterial coenoses from the neoproterozoic formations of the South margin of Siberian platform. Instruments, Methods and Missions for Astrobiology VI Proceeding of SPIE Bellingham, WA, 2003; 4939: 28-37.

(C) Borjigin et al.; Licensee Bentham Open.

This is an open access article licensed under the terms of the Creative Commons Attribution Non-Commercial License (http://creativecommons.org/licenses/by$\mathrm{nc} / 3.0 /$ ), which permits unrestricted, non-commercial use, distribution and reproduction in any medium, provided the work is properly cited. 